\title{
Growth and study of some gel grown group II single crystals of iodate
}

\author{
SHARDA J SHITOLE* and K B SARAF \\ PG Department of Physics, Pratap College, Amalner 425 401, India
}

MS received 12 March 2001; revised 7 July 2001

\begin{abstract}
Single crystals of calcium iodate and barium iodate were grown by simple gel technique by single diffusion method. The optimum conditions were established by varying various parameters such as $\mathrm{pH}$ of gel solution, gel concentration, gel setting time, concentration of the reactants etc. Crystals having different morphologies and habits were obtained. Prismatic, dendritic crystals of barium iodate and prismatic, needle shaped, hopper crystals of calcium iodate were obtained. Some of them were transparent, some transluscent, and few others were opaque. Both the crystals were studied using XRD, FT-IR, and thermal analysis. The crystals were doped by iron impurity. The effect of doping was studied using IR spectroscopy and thermal analysis.
\end{abstract}

Keywords. Silica gel; barium iodate; calcium iodate; XRD; FT-IR; TGA/DTA.

\section{Introduction}

A variety of crystals suitable for research and technology can be grown in silica gels. The gel medium prevents turbulence and being chemically inert, it provides a threedimensional crucible which permits the reagents to diffuse at a desirable controlled rate. Its softness and uniform nature of constraining forces that it exerts upon the growing crystals encourages orderly growth (Patel and Venkateswara Rao 1978).

The growth of single crystals in gel at ambient temperature, which are sparingly soluble in water, is a fascinating alternative to the techniques involving high temperature and expensive equipments (Sangwal and Patel 1974). During the last few years, successful application of gel growth technique has been demonstrated by the preparation of single crystals of alkaline earth metal iodate crystals (Joshi and Trivedi 1983). The gel growth technique appeared quite attractive for growing crystals of such compounds on account of its unique advantages in terms of crystals produced and the simplicity of the process (Armington and O'Connar 1968; Ranadive et al 1969; Blank and Brenner 1969; Blank et al 1969; Blank 1973).

In the present work, single crystals of barium iodate monohydrate, $\mathrm{Ba}\left(\mathrm{IO}_{3}\right)_{2}, \mathrm{H}_{2} \mathrm{O}$, calcium iodate monohydrate, $\mathrm{Ca}\left(\mathrm{IO}_{3}\right)_{2}, \mathrm{H}_{2} \mathrm{O}$, and calcium iodate hexahydrate, $\mathrm{Ca}\left(\mathrm{IO}_{3}\right)_{2}, 6 \mathrm{H}_{2} \mathrm{O}$ were grown by gel technique by single diffusion method. The optimum growth conditions for both the crystals were determined. As it has been

\footnotetext{
*Author for correspondence
}

observed that crystal habit is governed by kinetic rather than equilibrium condition (Joshi and Trivedi 1983), optimum conditions were established by varying various parameters such as gel concentration, $\mathrm{pH}$ of gel, gel aging time, concentration of reactants, concentration programming, effect of neutral gel, etc. The effect of doping on habits of crystals was also studied.

\section{Experimental}

Test tubes were used as crystallizing vessels. The silica gel was used as a growth media. Gel was prepared by using glacial acetic acid and sodium meta silicate having different $\mathrm{pH}$ values. The chemicals used for growth of doped and undoped barium iodate crystals were $\mathrm{CH}_{3} \mathrm{COOH}, \mathrm{Na}_{2} \mathrm{SiO}_{3}, \mathrm{BaCl}_{2}, \mathrm{Ba}\left(\mathrm{NO}_{3}\right)_{2}, \mathrm{KIO}_{3}, \mathrm{NaIO}_{3}$ and $\mathrm{FeCl}_{3}$. Similarly, the chemicals used for growth of doped and undoped calcium iodate crystals were $\mathrm{CH}_{3} \mathrm{COOH}$, $\mathrm{Na}_{2} \mathrm{SiO}_{3}, \mathrm{CaCl}_{2}, \mathrm{Ca}\left(\mathrm{NO}_{3}\right)_{2}, \mathrm{KIO}_{3}, \mathrm{NaIO}_{3}$ and $\mathrm{FeCl}_{3}$. All chemicals were of AR grade.

Different molar masses were tried to determine the optimum growth conditions. One of the reactants having different concentrations was incorporated into the gel. This solution was then transferred to borosil glass tube of diameter $2.5 \mathrm{~cm}$ and $25 \mathrm{~cm}$ in height. The mouth of the tube was covered by cotton plug. After setting of the gel, it was left for aging for different periods of time. Another reactant having different concentrations was then added as supernatant over the set gel. Experiments were carried out by changing the positions of both reactants. Experiments were also carried out by adding Fe impurity. This impurity of different concentrations and amounts was added to the gel. 
The chemical reactions inside the gel can be expressed as

$$
\mathrm{XCl}_{2}+2 \mathrm{YIO}_{3} \rightarrow \mathrm{X}\left(\mathrm{IO}_{3}\right)_{2}+2 \mathrm{YCl}
$$

or

$$
\mathrm{X}\left(\mathrm{NO}_{3}\right)_{2}+2 \mathrm{YIO}_{3} \rightarrow \mathrm{X}\left(\mathrm{IO}_{3}\right)_{2}+2 \mathrm{Y}\left(\mathrm{NO}_{3}\right)_{2},
$$

where $\mathrm{X}=\mathrm{Ba}$ or $\mathrm{Ca}$ and $\mathrm{Y}=\mathrm{K}$ or $\mathrm{Na}$.

\section{Results and discussion}

The various optimum conditions for growing crystals were found and are given in table 1 .

Different parameters such as concentration of reactants, $\mathrm{pH}$ of gel, impurities in the solvent, gel setting time, gel aging time, etc have considerable effect on growth rate. In the steady state of concentration gradient, growth rate also becomes steady which favours growth of well-developed crystals. However, very slow rate of growth along onedirection results in the platy crystals. Fast growth rate in one particular direction leads to the formation of elongated crystals like dendrites or hopper crystals. Low concentration of doping has less effect on the habit of both $\mathrm{Ba}$ and $\mathrm{Ca}$ iodate crystals. Even higher concentration of doping has no evident effect on habit of barium iodate crystals, but in case of calcium iodate crystals higher concentration of doping results in growth of platy, elongated crystals. Most of them are opaque. In both crystals Liesegang ring phenomenon has been observed (Henisch 1973). All types of calcium iodate crystals show the phenomenon of efflorescence, i.e. due to dehydration even at room temperature, transparent crystals become opaque. Most of the barium iodate crystals are opaque.

\section{Observations}

Various concentrations of reactants have various effects on the quality of crystals. Tables 2 and 3 summarize the effects on the habits of single crystals. Figure 1 shows dendritic growth of barium iodate crystals inside the test tube for high concentration of reactants. Figure 2 shows prismatic transparent crystals of barium iodate.

Figure 3 shows few prismatic transparent crystals of calcium iodate. At one end crystals are transluscent which is due to the inclusion of silica gel.

Table 1. Optimum conditions for growth of $\mathrm{Ba}\left(\mathrm{IO}_{3}\right)_{2}$ and $\mathrm{Ca}\left(\mathrm{IO}_{3}\right)_{2}$ crystals.

\begin{tabular}{lll}
\hline Conditions & $\mathrm{Ba}\left(\mathrm{IO}_{3}\right)_{2}$ & $\mathrm{Ca}\left(\mathrm{IO}_{3}\right)_{2}$ \\
\hline Density of sodium meta silicate solution & $1.04 \mathrm{~g} / \mathrm{cm}^{3}$ & $1.04 \mathrm{~g} / \mathrm{cm}^{3}$ \\
Amount of 2N acetic acid & $4 \mathrm{ml}$ & $4 \mathrm{ml}$ \\
pH of mixture & $4 \cdot 2$ & $4 \cdot 2$ \\
Temperature & $\mathrm{Room} \mathrm{temp.}$ & $\mathrm{Room}$ temp. \\
Concentration of $\mathrm{NaIO}_{3}$ or $\mathrm{KIO}_{3}$ & $0 \cdot 1 \mathrm{M}$ & $0.4 \mathrm{M}$ \\
Concentration of $\mathrm{BaCl}_{2}$ or $\mathrm{Ba}\left(\mathrm{NO}_{3}\right)_{2}$ & $0 \cdot 05 \mathrm{M}$ & - \\
Concentration of $\mathrm{CaCl}_{2}$ or $\mathrm{Ca}\left(\mathrm{NO}_{3}\right)_{2}$ & - & $1.0 \mathrm{M}$ \\
Gel setting time & 12 days & 12 days \\
Gel aging time & $120 \mathrm{~h}$ & $120 \mathrm{~h}$ \\
Period of growth & 4 weeks & 4 weeks \\
\hline
\end{tabular}

\begin{tabular}{|c|c|c|c|c|}
\hline $\begin{array}{l}\text { Conc. of reactant } \\
\text { in gel }\end{array}$ & $\begin{array}{l}\text { Conc. of reactant } \\
\text { above gel }\end{array}$ & Habit & Quality & $\begin{array}{l}\text { Size } \\
(\mathrm{mm})\end{array}$ \\
\hline $\begin{array}{l}\mathrm{NaIO}_{3} \text { or } \mathrm{KIO}_{3} \\
0 \cdot 4 \mathrm{M} \\
(3 \text { to } 5 \mathrm{ml})\end{array}$ & $\begin{array}{l}\mathrm{BaCl}_{2} \text { or } \mathrm{Ba}\left(\mathrm{NO}_{3}\right)_{2} \\
0 \cdot 1 \text { to } 0 \cdot 2 \mathrm{M} \\
(20 \mathrm{ml})\end{array}$ & Dendritic & Opaque, brittle & 10 to $20 \times 1$ \\
\hline $\begin{array}{l}\mathrm{BaCl}_{2} \text { or } \mathrm{Ba}\left(\mathrm{NO}_{3}\right)_{2} \\
0 \cdot 1 \mathrm{M} \\
(3 \text { to } 5 \mathrm{ml})\end{array}$ & $\begin{array}{l}\mathrm{NaIO}_{3} \text { or } \mathrm{KIO}_{3} \\
0.4 \mathrm{M} \\
(20 \mathrm{ml})\end{array}$ & Dendritic & Opaque, brittle & 10 to $20 \times 1$ \\
\hline $\begin{array}{l}\mathrm{NaIO}_{3} \text { or } \mathrm{KIO}_{3} \\
0 \cdot 1 \mathrm{M} \\
(3 \text { to } 5 \mathrm{ml})\end{array}$ & $\begin{array}{l}\mathrm{BaCl}_{2} \text { or } \mathrm{Ba}\left(\mathrm{NO}_{3}\right)_{2} \\
0.025 \text { to } 0.05 \mathrm{M} \\
(20 \mathrm{ml})\end{array}$ & $\begin{array}{l}\text { Prismatic } \\
\text { Prismatic } \\
\quad \text { pyramidal }\end{array}$ & Opaque, few transparent & $\begin{array}{l}2 \times 2 \times 1 \cdot 5 \\
3 \times 2 \times 2\end{array}$ \\
\hline $\begin{array}{l}\mathrm{BaCl}_{2} \text { or } \mathrm{Ba}\left(\mathrm{NO}_{3}\right)_{2} \\
0.050 \mathrm{M} \\
(3 \text { to } 5 \mathrm{ml})\end{array}$ & $\begin{array}{l}\mathrm{NaIO}_{3} \text { or } \mathrm{KIO}_{3} \\
0 \cdot 1 \mathrm{M} \\
(20 \mathrm{ml})\end{array}$ & $\begin{array}{l}\text { Prismatic } \\
\text { Prismatic } \\
\quad \text { pyramidal }\end{array}$ & Opaque, few transparent & $\begin{array}{l}2 \times 2 \times 1 \cdot 5 \\
3 \times 2 \times 2\end{array}$ \\
\hline
\end{tabular}

Table 2. Effect of concentration of reactants on habit quality and size of $\mathrm{BaIO}_{3}$ crystals. 
Table 3. Effect of concentration of reactants on habit quality and size of $\mathrm{CaIO}_{3}$ crystals.

\begin{tabular}{|c|c|c|c|c|}
\hline $\begin{array}{l}\text { Conc. of reactant } \\
\text { in gel }\end{array}$ & $\begin{array}{l}\text { Conc. of reactant } \\
\text { above gel }\end{array}$ & Habit & Quality & $\begin{array}{l}\text { Size } \\
(\mathrm{mm})\end{array}$ \\
\hline $\begin{array}{l}\mathrm{NaIO}_{3} \text { or } \mathrm{KIO}_{3} \\
0 \cdot 4 \mathrm{M} \\
(3 \text { to } 5 \mathrm{ml})\end{array}$ & $\begin{array}{l}\mathrm{CaCl}_{2} \text { or } \mathrm{Ca}\left(\mathrm{NO}_{3}\right)_{2} \\
1 \text { to } 2 \mathrm{M} \\
(20 \mathrm{ml})\end{array}$ & $\begin{array}{l}\text { Prismatic } \\
\text { Prismatic pyramidal } \\
\text { Prismatic needles }\end{array}$ & $\begin{array}{l}\text { Good } \\
\text { Good } \\
\text { Good }\end{array}$ & $\begin{array}{c}2 \times 2 \times 2 \\
5 \times 2 \times 2 \\
10 \times 2 \times 2\end{array}$ \\
\hline $\begin{array}{l}\mathrm{NaIO}_{3} \\
0 \cdot 4 \mathrm{M} \\
(8 \mathrm{ml})\end{array}$ & $\begin{array}{l}\mathrm{CaCl}_{2} \\
1 \mathrm{M} \\
(20 \mathrm{ml})\end{array}$ & $\begin{array}{l}\text { Hopper } \\
\text { Prismatic needles }\end{array}$ & $\begin{array}{l}\text { Medium } \\
\text { Good }\end{array}$ & $\begin{array}{c}10 \times 3 \times 2 \\
8 \times 2 \times 2\end{array}$ \\
\hline $\begin{array}{l}\mathrm{CaCl}_{2} \\
1 \mathrm{M} \\
\text { (3 to } 5 \mathrm{ml} \text { ) }\end{array}$ & $\begin{array}{l}\mathrm{NaIO}_{3} \\
0.4 \mathrm{M} \\
(20 \mathrm{ml})\end{array}$ & $\begin{array}{l}\text { Prismatic } \\
\text { Prismatic pyramidal } \\
\text { Prismatic needles }\end{array}$ & $\begin{array}{l}\text { Good } \\
\text { Good } \\
\text { Good }\end{array}$ & $\begin{array}{l}2 \times 2 \times 2 \\
3 \times 2 \times 2 \\
8 \times 2 \times 2\end{array}$ \\
\hline $\begin{array}{l}\mathrm{KIO}_{3} \\
0 \cdot 4 \mathrm{M} \\
(3 \text { to } 5 \mathrm{ml})\end{array}$ & $\begin{array}{l}\mathrm{CaCl}_{2} \\
0 \cdot 5 \text { to } 1 \mathrm{M} \\
(20 \mathrm{ml})\end{array}$ & Prismatic & Good & $2 \times 2 \times 2$ \\
\hline $\begin{array}{l}\mathrm{CaCl}_{2} \\
1 \mathrm{M} \\
\text { (3 to } 5 \mathrm{ml} \text { ) }\end{array}$ & $\begin{array}{l}\mathrm{KIO}_{3} \\
0 \cdot 1 \text { to } 0 \cdot 4 \mathrm{M} \\
(20 \mathrm{ml})\end{array}$ & $\begin{array}{l}\text { Prismatic } \\
\text { Prismatic pyramidal }\end{array}$ & $\begin{array}{l}\text { Good } \\
\text { Good }\end{array}$ & $\begin{array}{l}2 \times 2 \times 2 \\
3 \times 2 \times 2\end{array}$ \\
\hline
\end{tabular}

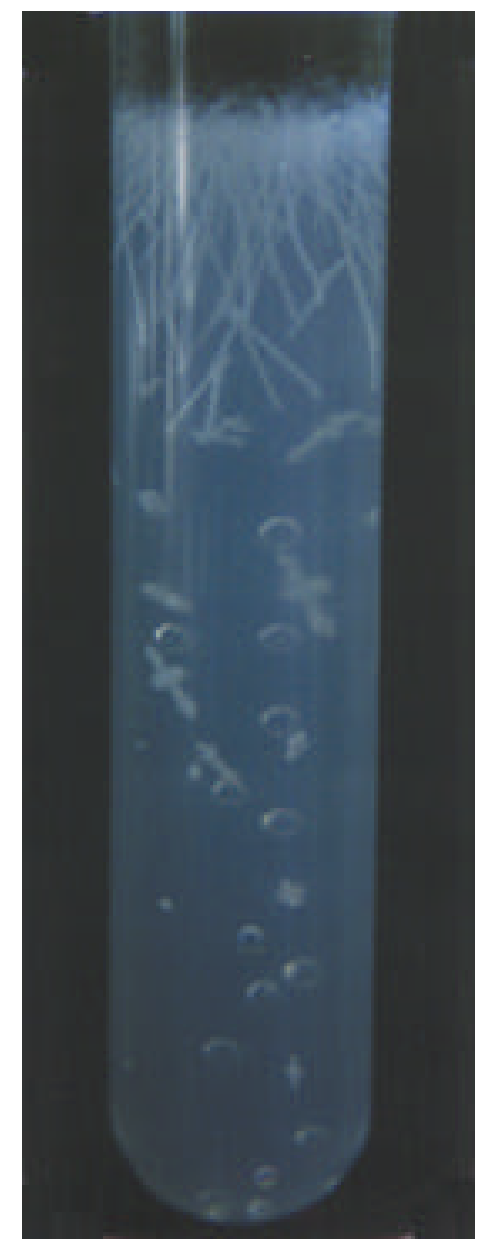

Figure 1. Dendritic growth of barium iodate crystals.

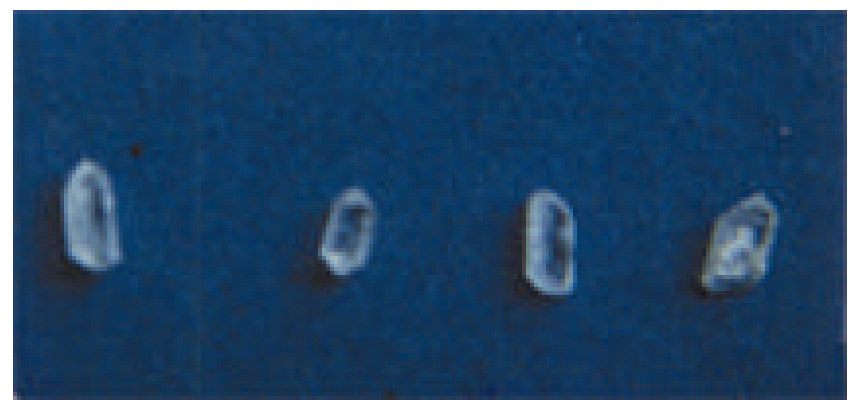

Figure 2. Prismatic transparent crystals of barium iodate.

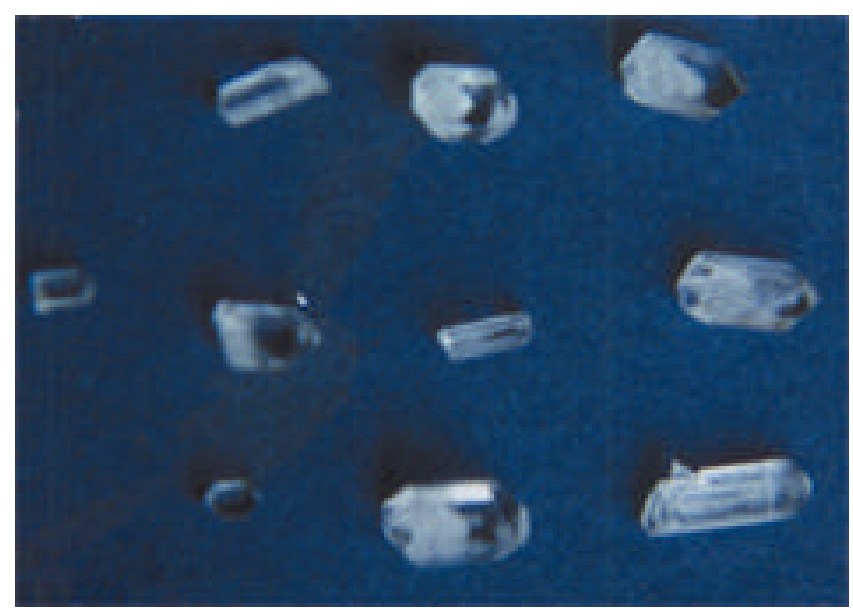

Figure 3. Prismatic transparent crystals of calcium iodate. 


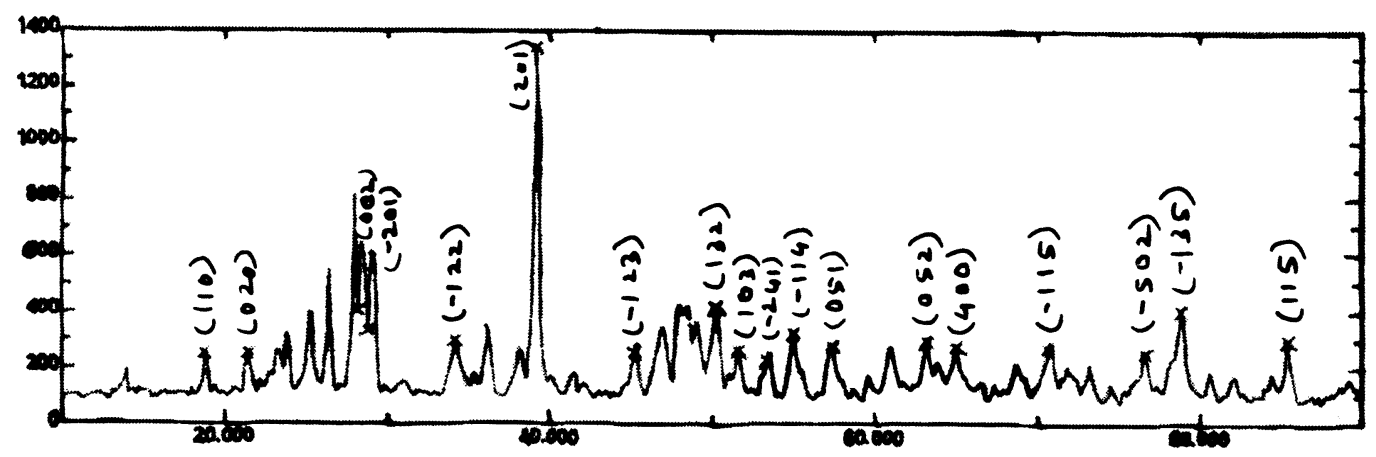

Figure 4. X-ray diffractogram of barium iodate.

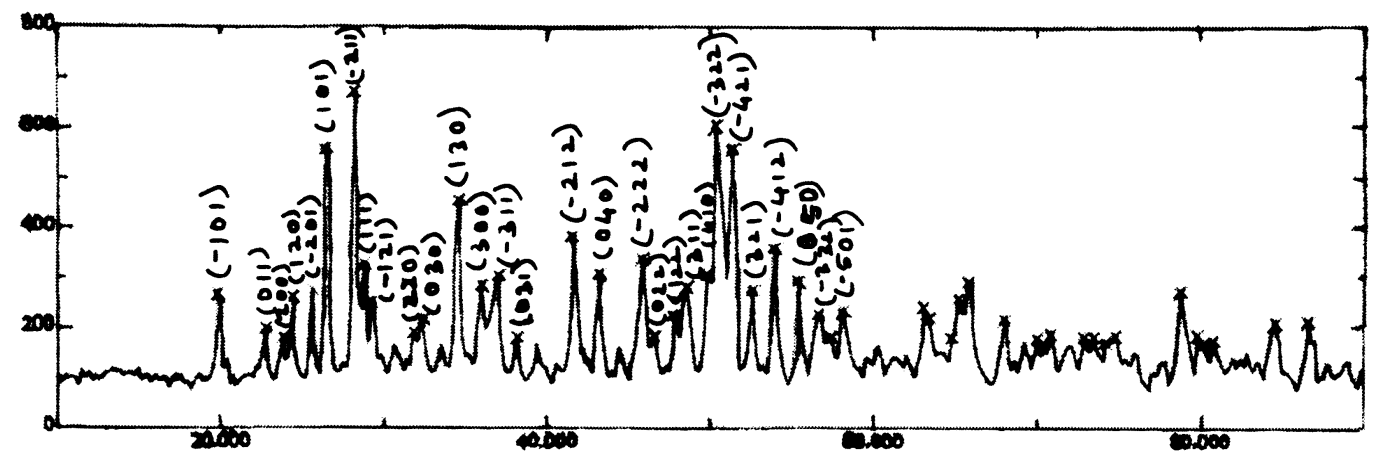

Figure 5. X-ray diffractogram of calcium iodate.

\section{Characterization}

Doped and undoped crystals of barium and calcium iodates were characterized by XRD, FT-IR and thermal analysis.

\section{$5.1 \quad X$-ray diffraction}

X-ray powder diffractograms were recorded using Minislex model, Rigaku, ( $\mathrm{CuK} \alpha$ radiation, scanning speed $10 \%$ min). X-ray diffractograms of $\mathrm{Ba}$ and $\mathrm{Ca}$ iodates are shown in figures 4 and 5 , respectively.

From the diffractograms, $d$-values and $h k l$ were computed. The computer program POWD (an Interactive Powder Diffraction Data Interpretation and Indexing Program Version 2.2) was used to calculate ' $d$ ' values. Calculated ' $d$ ' values agree well with reported ones. Calculated unit cell parameters are given in table 4.

\subsection{Fourier transform infrared (FT-IR) spectral analysis}

FT-IR is used for structural analysis. In the present investigation, spectra were obtained on Perkin-Elmer Model 1600 FT-IR spectrophotometer at University of Pune. Figures $6 \mathrm{a}$ and $\mathrm{b}$ show FT-IR spectra of $\mathrm{Ba}\left(\mathrm{IO}_{3}\right)_{2}, \mathrm{H}_{2} \mathrm{O}$ and $\mathrm{Fe}$ doped $\mathrm{Ba}\left(\mathrm{IO}_{3}\right)_{2}, \mathrm{H}_{2} \mathrm{O}$, respectively. Figures $7 \mathrm{a}$ and $b$ show FT-IR spectra of $\mathrm{Ca}\left(\mathrm{IO}_{3}\right)_{2}, \mathrm{H}_{2} \mathrm{O}$ and $\mathrm{Fe}$ doped
Table 4. Calculated unit cell parameters.

\begin{tabular}{lll}
\hline Parameter & $\mathrm{Ba}\left(\mathrm{IO}_{3}\right)_{2}$ & $\mathrm{Ca}\left(\mathrm{IO}_{3}\right)_{2}$ \\
\hline System & Monoclinic & Monoclinic \\
$a$ & $7.9080 \AA$ & $6 \cdot 2133 \AA$ \\
$b$ & $8 \cdot 3360 \AA$ & $8 \cdot 2853 \AA$ \\
$c$ & $4.6590 \AA$ & $6 \cdot 8624 \AA$ \\
$\beta$ & $108.899 \AA$ & $112.714 \AA$ \\
$V$ & 290.60 & $325 \cdot 860$ \\
\hline
\end{tabular}

$\mathrm{Ca}\left(\mathrm{IO}_{3}\right)_{2}, 6 \mathrm{H}_{2} \mathrm{O}$, respectively. The spectra were scanned by placing sample $\mathrm{KBr}$ pellet in the sample beam in the range $500-4000 \mathrm{~cm}^{-1}$.

The bands at $3376 \mathrm{~cm}^{-1}$ are due to $\mathrm{O}-\mathrm{H}$ stretching and at $1608 \mathrm{~cm}^{-1}$ are due to $\mathrm{H}-\mathrm{O}-\mathrm{H}$ bending. Bands due to vibrations involving metal, iodine, and oxygen atoms are found predominantly near $750-800 \mathrm{~cm}^{-1}$. Fundamental infrared frequencies, observed in all iodate compounds in general, are also found in present FT-IR analysis, which confirms the iodate group of grown crystals. Fundamental frequencies that have been observed are $v_{1}$ (symmetric stretching) at $758.5 \mathrm{~cm}^{-1}$ and $v_{3}$ (asymmetric stretching) at $778.70 \mathrm{~cm}^{-1}$. The dominant absorption bands are found at $700-800 \mathrm{~cm}^{-1}$ in all iodate compounds (Nakamoto 1970) and can be expected to contain $v_{1}, v_{3}$ as well as possible splitting of $v_{3}$. From the spectral analysis it is clear that in case of barium iodate 

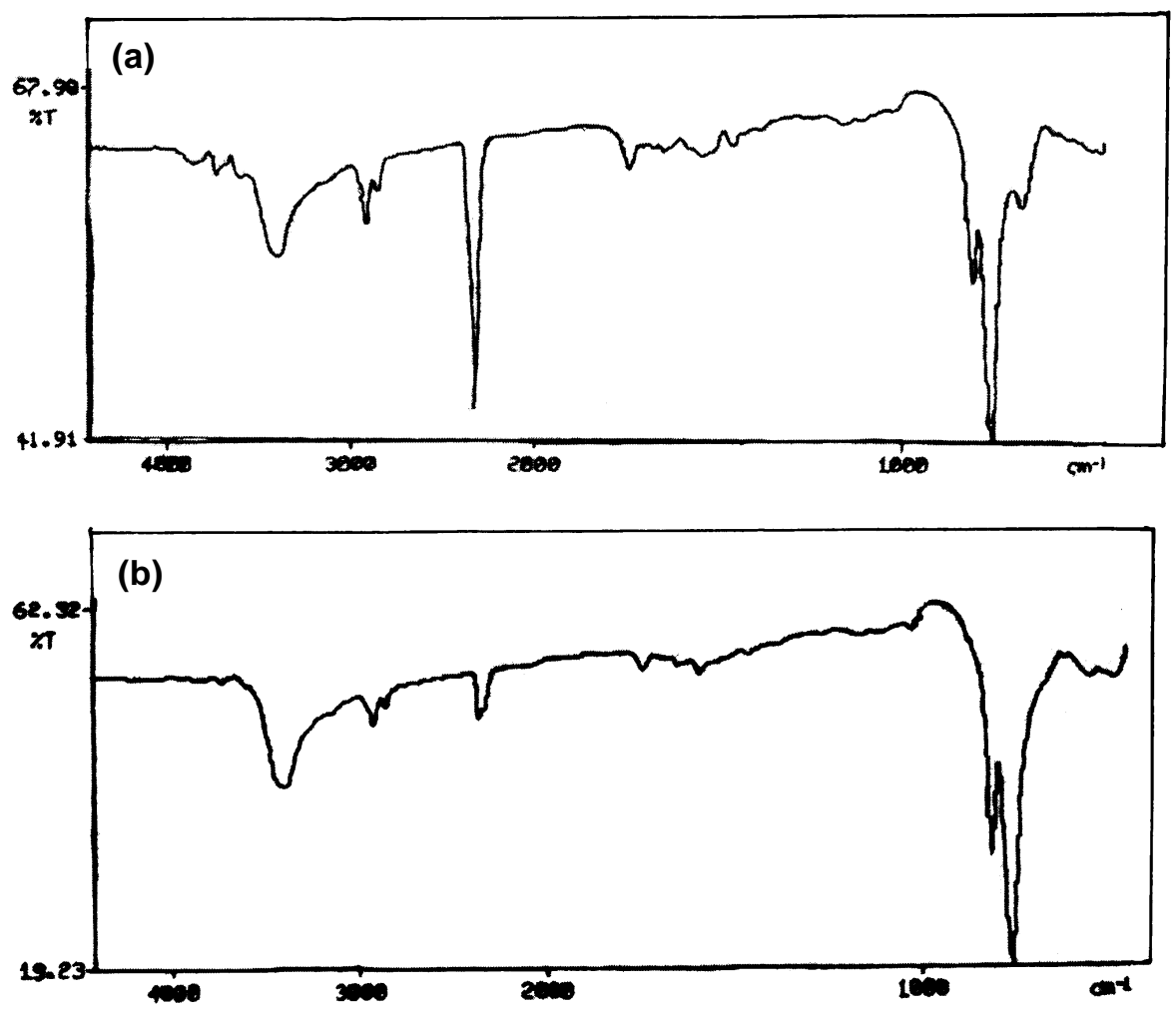

Figure 6. FT-IR spectra of (a) undoped barium iodate, monohydrate and (b) Fe doped barium iodate, monohydrate.
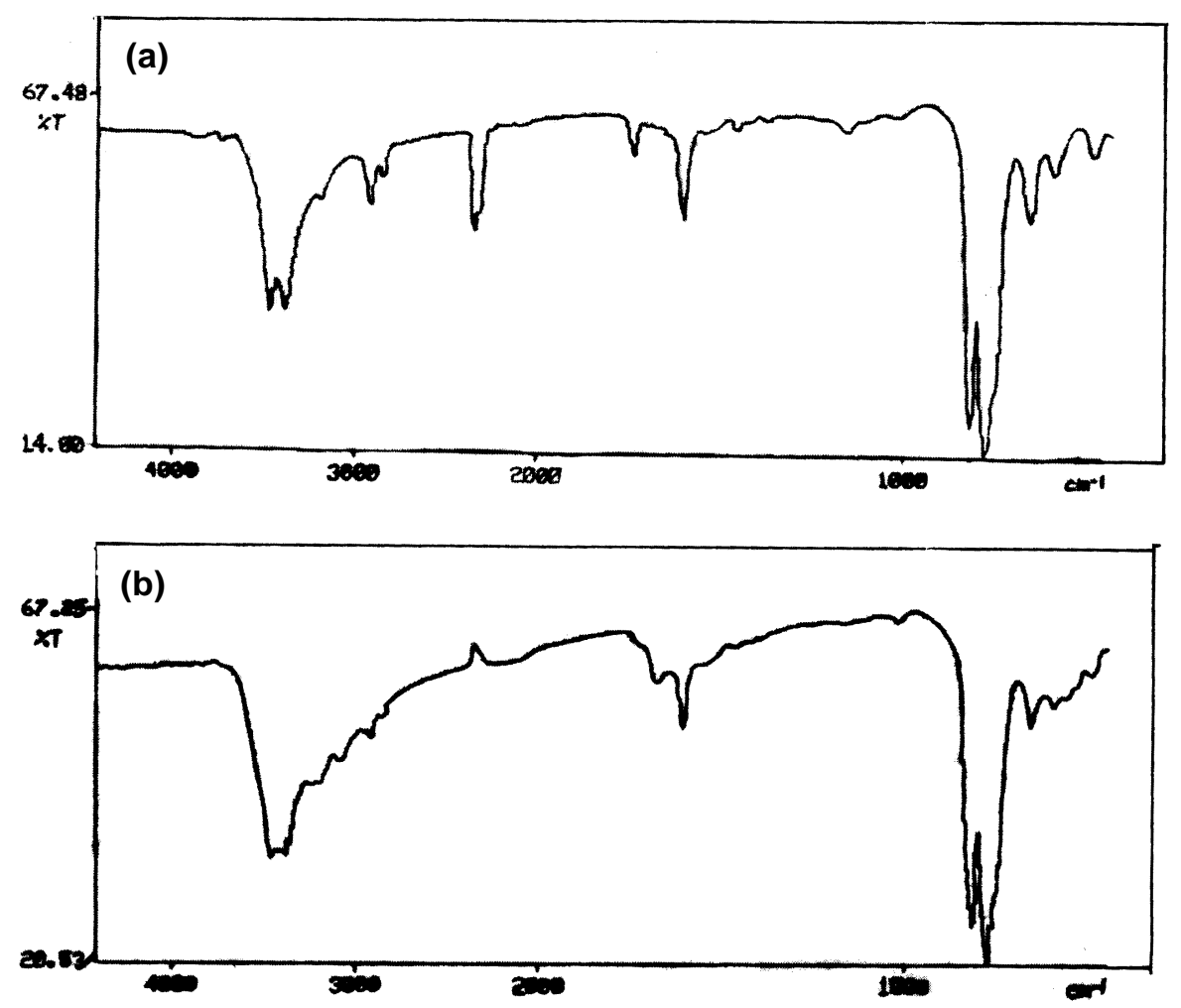

Figure 7. FT-IR spectra of (a) undoped calcium iodate, monohydrate and (b) Fe doped calcium iodate, hexahydrate. 
crystals there is no difference in crystal structure due to doping, but in Fe doped calcium iodate crystals the $\mathrm{O}-\mathrm{H}$ stretch bands in the region $2300-3700 \mathrm{~cm}^{-1}$ are much widened. It is due to inclusion of water molecules.

\subsection{Thermal analysis}

TGA and DTA studies of undoped and Fe doped barium and calcium iodate crystals were carried out at NCL, Pune.

5.3a Barium iodate: DTA and TGA curves for undoped and Fe doped barium iodate are shown in figures 8 and 9 , respectively.

TGA curve shows that the compound is stable up to $80^{\circ} \mathrm{C}$. It looses weight in the temperature range $75-$ $125^{\circ} \mathrm{C}$. The $5 \%$ weight loss is due to dehydration of one water molecule. There is no further weight loss up to $550^{\circ} \mathrm{C}$. It shows that barium iodate crystals are monohydrated. Anhydrous barium iodate decomposes in the temperature range $550-630^{\circ} \mathrm{C}$. The $50 \%$ weight loss indicates that this decomposition should be due to the formation of compound $\mathrm{Ba}_{5}\left(\mathrm{IO}_{6}\right)_{2}$.
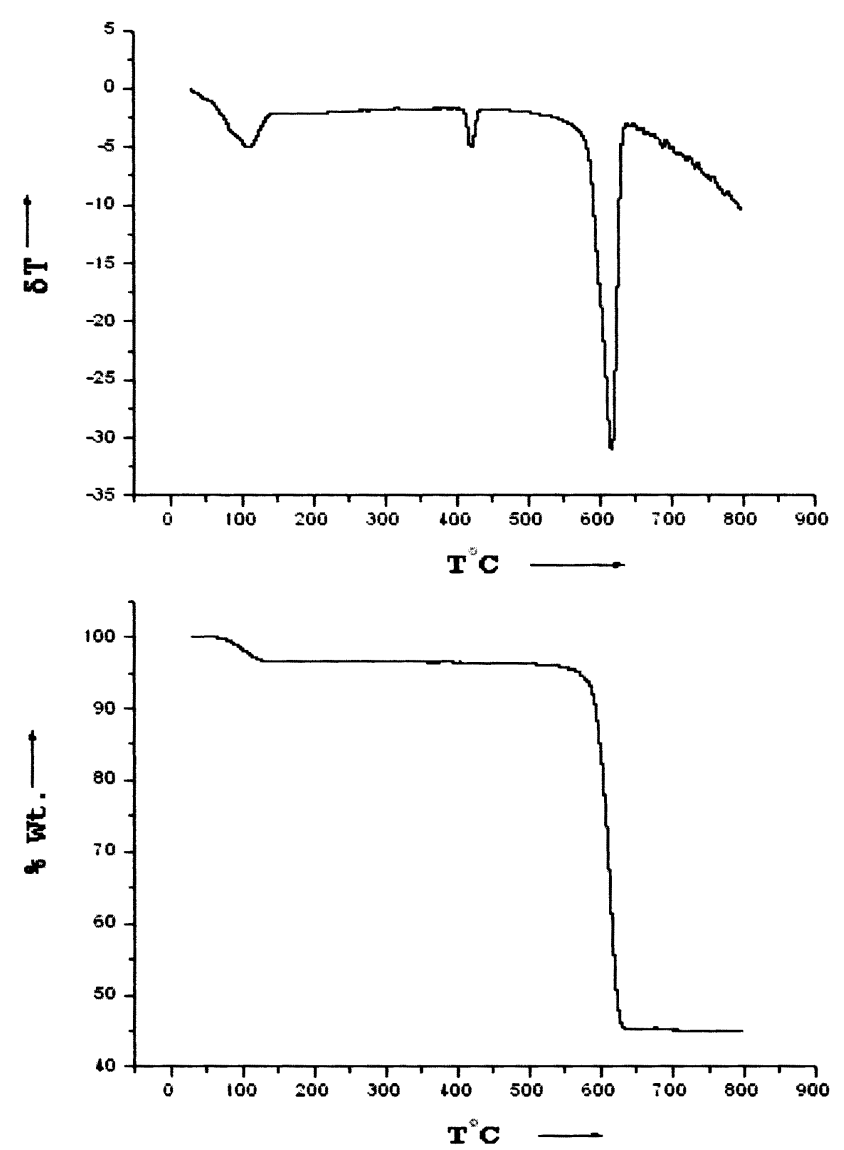

Figure 8. DTA and TGA curves for undoped barium iodate, monohydrate.
DTA curve of this compound shows two peaks at 75$125^{\circ} \mathrm{C}$ and $550-630^{\circ} \mathrm{C}$. Similar results are obtained for $\mathrm{Fe}$ doped barium iodate crystals.

5.3b Calcium iodate: DTA and TGA curves for undoped and $\mathrm{Fe}$ doped calcium iodate are shown in figures 10 and 11 , respectively.

In case of undoped calcium iodate crystals, 5\% weight loss due to dehydration of one water molecule is in the temperature range $225-280^{\circ} \mathrm{C}$. There is no further weight loss up to $550^{\circ} \mathrm{C}$. It shows that calcium iodate crystals are monohydrated. The further $50 \%$ weight loss in the temperature range $550-660^{\circ} \mathrm{C}$ should be due to decomposition reaction producing compound $\mathrm{Ca}_{5}\left(\mathrm{IO}_{6}\right)_{2}$. DTA curve of this compound shows two peaks at $225-280^{\circ} \mathrm{C}$ and $550-660^{\circ} \mathrm{C}$.

However, Fe doped calcium iodate crystals show different results. The initial $8 \%$ weight loss occurs in the temperature range $90-125^{\circ} \mathrm{C}$. It is due to loss of four water molecules. The resulting product is $\mathrm{Ca}\left(\mathrm{IO}_{3}\right)_{2}$, $2 \mathrm{H}_{2} \mathrm{O}$. Further $2 \%$ weight loss in the temperature range $125-240^{\circ} \mathrm{C}$ is due to loss of one water molecule producing $\mathrm{Ca}\left(\mathrm{IO}_{3}\right)_{2}, \mathrm{H}_{2} \mathrm{O}$. Further $2 \%$ weight loss in the temperature range $240-300^{\circ} \mathrm{C}$ is due to loss of one more
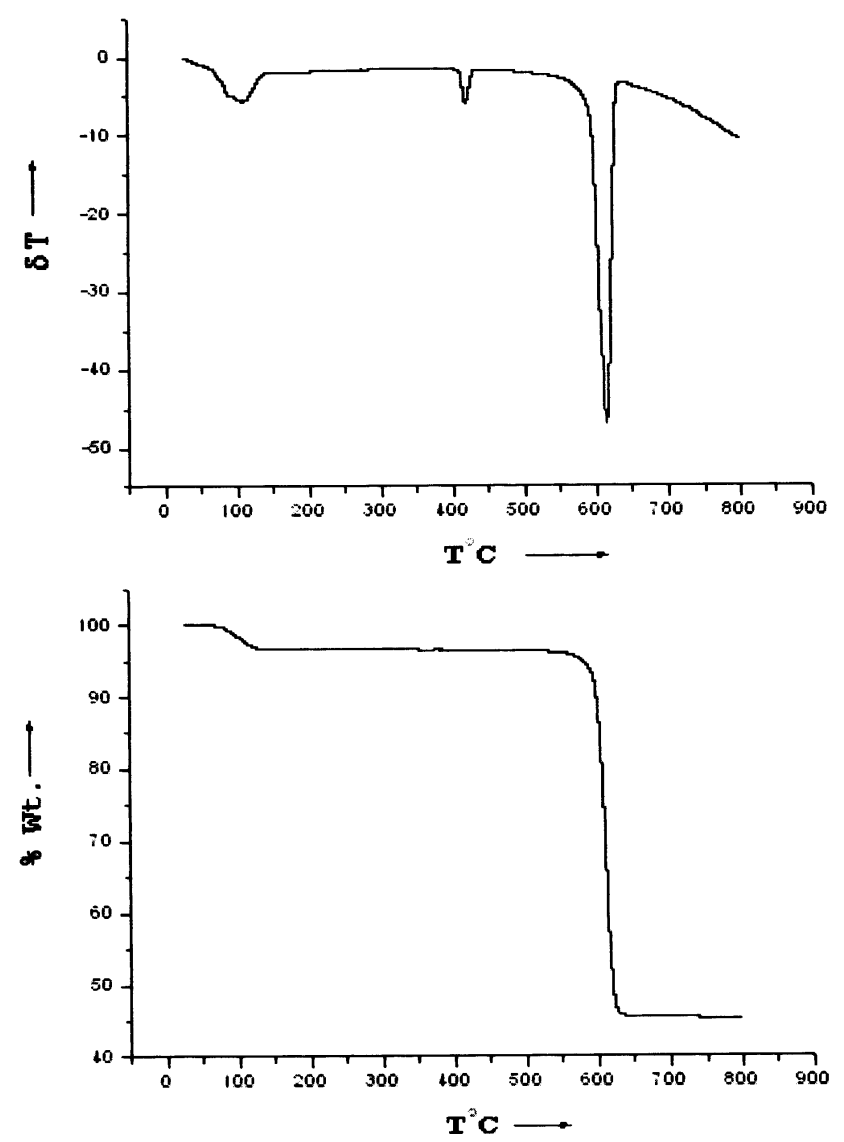

Figure 9. DTA and TGA curves for Fe doped barium iodate, monohydrate. 

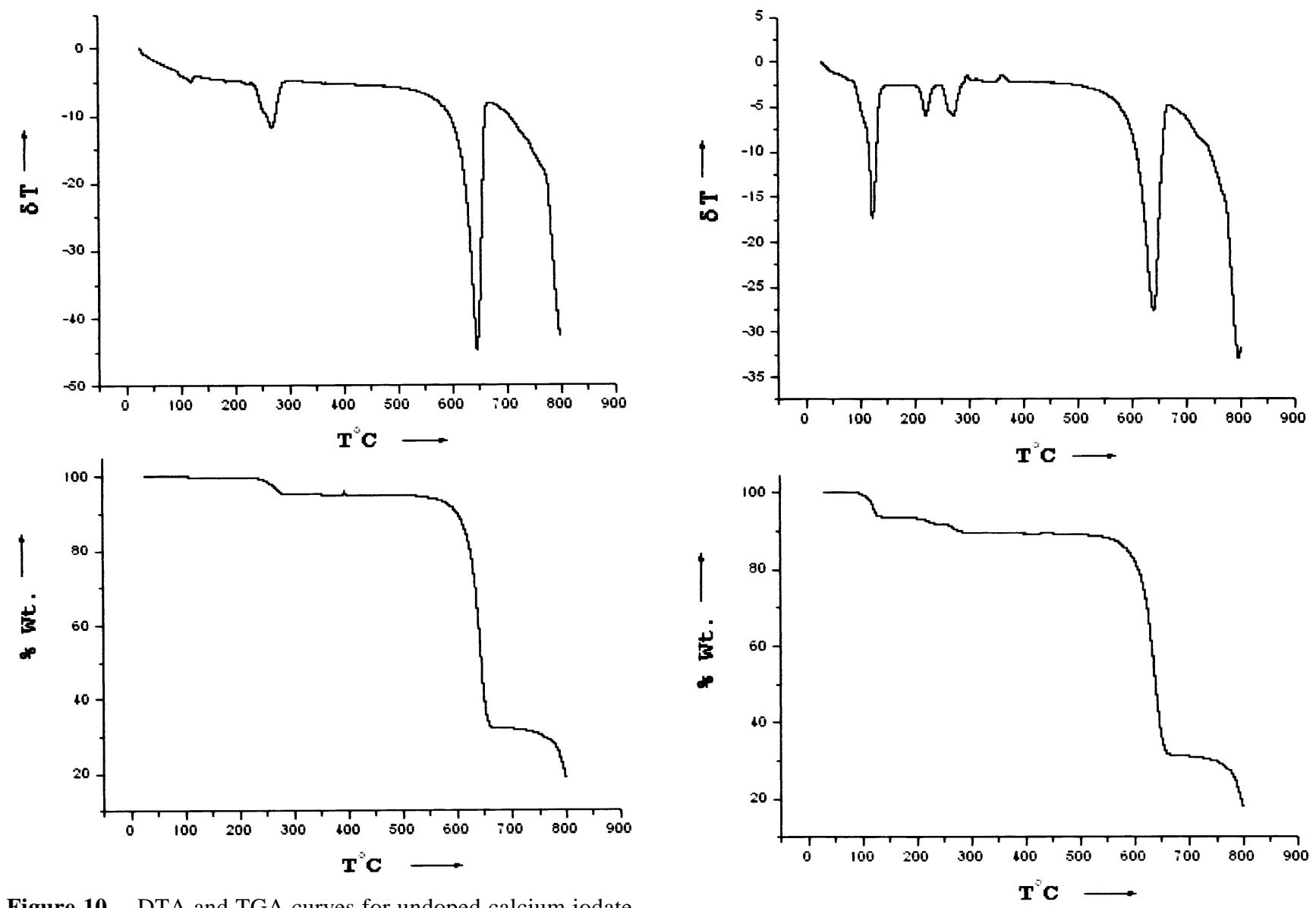

Figure 10. DTA and TGA curves for undoped calcium iodate, monohydrate.

water molecule producing anhydrous calcium iodate. The compound is stable up to $550^{\circ} \mathrm{C}$. It shows that $\mathrm{Fe}$ doped calcium iodate crystals are hexahydrate. Further 55\% weight loss in the temperature range $550-660^{\circ} \mathrm{C}$ indicates decomposition reaction producing compound $\mathrm{Ca}_{5}\left(\mathrm{IO}_{6}\right)_{2}$.

DTA curves of the same compound show its peaks at 90- $125^{\circ} \mathrm{C}, 125-240^{\circ} \mathrm{C}, 240-300^{\circ} \mathrm{C}$, and $550-660^{\circ} \mathrm{C}$.

\section{Conclusions}

From the above studies we observe that:

(I) Gel growth technique is suitable for growing crystals of barium and calcium iodate.

(II) Different habits of $\mathrm{Ba}$ and $\mathrm{Ca}$ iodate crystals can be obtained by changing parameters like gel density, gel aging, $\mathrm{pH}$ of gel, concentration of reactants, concentration of impurities, etc.

(III) Well known Liesegang phenomenon is observed in the growth of both barium and calcium iodate crystals.

(IV) XRD results obtained, especially $d$-values, match very well with the standard JCPDS data.

Figure 11. DTA and TGA curves for Fe doped calcium iodate, hexahydrate.

(V) Doping of Fe changes the structure of calcium iodate monohydrate to calcium iodate hexahydrate. Doping has no such effect on barium iodate crystals. FT-IR spectra and thermal analysis confirm the above results.

\section{Acknowledgements}

The authors are grateful to Prof. P A Wani, Department of Physics, Pratap College, Amalner, for providing laboratory facilities. Our special thanks are due to Prof. P P Patil, Director, Physical Sciences, NMU, Jalgaon, for help in XRD analysis and Prof. N R Shah, Pratap College, Amalner, for fruitful discussion on IR analysis. One of us (SJS) sincerely thanks the University Grants Commission, New Delhi for the award of a teacher fellowship under the Faculty Improvement Programme.

\section{References}

Armington A F and O'Connar J J 1968 J. Cryst. Growth 3/4 367 Blank Z 1973 J. Cryst. Growth 18281 
Blank Z and Brenner W 1969 Nature 22279

Blank Z, Brenner W and Okamoto Y 1969 Mater. Res. Bull. 3 829

Henisch H K 1973 Crystal growth in gel (London: Pennsylvania State University Press)

Joshi M S and Trivedi S G 1983 Indian J. Pure \& Appl. Phys. 21435

Nakamoto K 1970 Infrared spectra of inorganic and coordina- tion compounds (New York: John Wiley and Sons Inc) 2nd edn

Patel A R and Venkateswara Rao A 1978 J. Cryst. Growth 43 351

Ranadive D, Blank Z, Brenner W and Okamoto Y 1969 Nature 223829

Sangwal K and Patel A R 1974 J. Cryst. Growth 23 282 